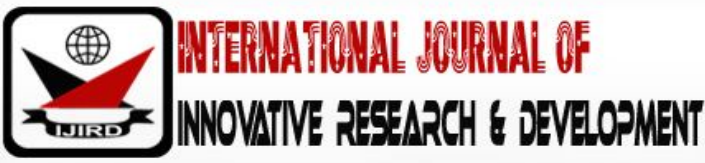

ISSN 2278 - 0211 (Online)

\section{Influence of the Grade Achieved in Agriculture at Kenya Certificate of Secondary Education Examination on Performance in Farming in Kenya}

\author{
Dr. Mutiso, Stephen Kyalo \\ Assistant Lecturer, School of Education, University of Nairobi, Kenya \\ Mulwa, Peter Kyalo \\ Assistant Lecturer, School of Education, University of Nairobi, Kenya
}

\begin{abstract}
:
Farming is a major contributor to the economic development of Kenya. It is the source of livelihood for over 80 percent of the total population. Agriculture education in secondary school was expected to revitalise the agriculture sector. Yet, despite the teaching of agriculture schools production from the sector is on the decline. A survey was conducted to establish the influence of the grade achieved in agriculture at school and performance in farming after school. The target population comprised of farmers with agriculture knowledge from secondary school. A sample of 100 respondents was obtained through snowball method. Ex-post facto/ survey design was employed. Structured questionnaires were used to obtain data. Descriptive statistics was used to analyse the objective, while inferential statistics was used for the hypothesis. Findings from the survey revealed a non-correlationship between agriculture grades and performance in farming. The conclusion drawn from the survey disclosed the grade obtained at school had no statistical relationship with performance in farming. The recommendation was that, agriculture education at secondary school should be reviewed and refocused more on pragmatism besides acquisition of quality grades. Lastly, secondary school agriculture education should be backed up with specialised training after school to adapt one to farming.
\end{abstract}

Keywords: Influence, performance, farming, grade

\section{Introduction}

Kenya's economy is agriculturally based (Government of Kenya (GOK, 2006). It is the livelihood of over 80 percent of the Kenyan populations who live in the rural areas and practice farming in small-scale holdings (Chitere \& Doorne, 1985). Despite enormous efforts to industrialize, Kenya has remained an agricultural nation since independence (Kipkemei, 2004). Farming serves as a source of food, raw materials for industries, employment, foreign exchange, market for industrial goods, capital for national development, and helps to correct the balance of trade deficit (Kipkemei, 2004).

The main objective of the 8-4-4 system of education which was introduced in Kenya in 1985 is to prepare youth for selfreliance (Oluoch, 1982). It means to transmit relevant attitudes, knowledge and skills needed in life after school (Oluoch, 1982). This was as a result of the realization that, the previous (7-4-2-3) system of education did not respond adequately to the needs of the country people. Technical and vocational subjects previously taught only in a few technical schools were recommended for introduction in all other secondary schools (Kenya Institute of Education (KIE), 1985). This was to ensure secondary schools graduates have scientific and practical skills that can be utilized in self-employment, salaried employment or further training.

Vocational agriculture education therefore became the preference of choice by many schools (KIE, 2002). It was identified as a major vehicle for transmitting farming skills to the youth (Kipkemei, 2004). It was hoped it would orientate them better to exploit their immediate environment for livelihoods. According to KIE (1992), its general objectives were thus formulated as follows:

- To develop an understanding of agriculture, and its importance to the family and the nation;

- to promote interest in agriculture as industry, and create awareness of the opportunities existing in agriculture and related sectors;

- to demonstrate that farming is a dignified and profitable occupation;

- to enhance skills needed in carrying out agricultural practices;

- to provide background for further studies in agriculture; 
- to develop self-reliance, resourcefulness, and problem-solving abilities in agriculture;

- to develop occupational out-look in agriculture;

- to enable schools to take an active part in national development through agricultural activities;

- to create awareness of the role of agriculture in industrial and technological development;

- to enhance understanding of the role of technology and industrialization in agricultural development;

- to promote agricultural activities which enhance environmental conservation; and

- To promote consciousness of healthy promoting activities in agricultural production.

In order to achieve the stated objectives, especially the occupational ones (ii, iii, vi, vii, ix and x), agricultural skills and knowledge were recommended to be taught both theoretically in a formal classroom setting, and practically in a school farm/ laboratory by professionally qualified teachers (KIE, 2002).

Kenyan youth constitute 78.31 percent of the total population (Population Census, 2009). The youth by definition refer to persons in the period between teenage and young adulthood (United Nations Education, Science and Cultural Organization (UNESCO, 1998). The World Bank (2008) defines youth as comprising to persons falling within the age group of 13 - 15 years. The youth add up to about 29 million and comprise of 61 percent of unemployed Kenyans (GOK, 2009). Given the high population growth in Kenya, the youth population is expected to double by 2045, further increasing pressure on job creation (World Bank (WB), 2009). It is, therefore, expected that, most of the employment opportunities that will be created will be agriculture related and will target these youth (Waldie \& Mulhall, 2002). The role of education in employment creation is very critical. It calls for a better focus by education systems on skills development, preparing youth for the transition to work, and for strong public-private partnerships. Modern agriculture and non-farm activities have considerable potential for job and wealth creation and may absorb large numbers of youth who currently crowd the urban towns and cities with underemployment (WB, 2009).

\subsection{Statement of the Problem}

The role of agriculture in Kenya's economic development is vital. There can be no economic growth without substantial growth in agricultural productivity. This underlies the reason why agricultural education was integrated in primary and secondary schools curricula. The motive was to create self-employment in farming among secondary school agriculture graduates, an occupation associated with the poor and uneducated people in Kenya. The problem is it is now past a quarter of a century since the advent of 8-4-4 system of education, which emphasized on self-reliance through selfemployment. Yet despite this, few secondary school leavers with agriculture knowledge and skills are taking up farming irrespective of whether they are in any formal employment or not. Of major concern, the country continues to experience poverty, and dependence on donor countries for food and non-food agricultural commodities. The contribution of agriculture knowledge to the performance in farming by secondary school agriculture graduates has not been systematically investigated and documented. It is against this background that, the survey on the influence of the grade achieved in agriculture at Kenya certificate of secondary education examination and performance in farming was carried out.

\subsection{Purpose of the Survey}

The purpose of this survey was to investigate the influence of the grade achieved in agriculture at Kenya certificate of secondary education examination on performance in farming.

\subsection{Objectives of the Study}

The objective that guided the survey was to examine whether the grade achieved in agriculture at Kenya Certificate of Secondary Education (KCSE) examinations influences performance in farming among secondary school agriculture graduates (SSAGs).

\subsection{Hypotheses of the Study}

The hypothesis formulated from the objective was;

- $\mathrm{HO}_{1}$ : There is no statistically significant influence of the grade achieved in agriculture at Kenya Certificate of Secondary Education (KCSE) examinations influences performance in farming among secondary school agriculture graduates (SSAGs).

\section{Literature Review}

\subsection{Youth and Unemployment in Africa}

World Bank report (2009) paints a gloomy picture on youth employment in Africa which warns that, the worst is yet to come unless policy interventions are urgently made. Youth aged between 15 and 24 and numbering about 200 million are increasingly finding it difficult to find jobs. Most fall off to grow the "reserve army" that is people who are actively looking for jobs but cannot find one. This transition to the labour market is marked by periods of unemployment or underemployment and is fraught with frustration. Currently, making up just over one-third of working-age population, unemployment in youth is so high they account for 60 percent of the "reserve army". Steadily, worsening over the years, youth joblessness and 
underemployment on the continent are assuming crisis proportions, particularly in the wake of the current global economic recession. Each year, 7-10 million youth enter the job market in Africa, often directly from school, yet only about 10 percent find wage employment, mostly in farming, which provides over 65 percent of total employment. To address the problem of youth unemployment, countries have to make progress on many dimensions. In the medium to long-term, the solution lies in rapid and labour-absorbing growth (World Bank, 2009).

In Kenya, the 2006 World population data sheet shows that population will grow by 87 percent to 67 million by 2050, from about 38.4 million currently, half of them aged below 24 (GOK, 2009). This will further pull youth unemployment to crisis proportions. To address this crisis, the Government of Kenya launched the Kshs. 15 billion Kazi Kwa Vijana (Jobs for Youth) initiative in March, 2009, which was expected to create 300,000 jobs in six months. However, more needs to be done in terms of creating a more conducive environment for the private sector to invest in labour intensive business. This calls into play all the macro, micro, and regulatory measures that attract investment, particularly from the private sector, and promote growth, including farming and the rural areas (World Bank, 2009).

\subsection{Agriculture and Community Development}

Schools play a significant role in terms of socio-economic empowerment of the community. It is a tool for advancement of economic strategies in communities. It's also the general enlightenment of the masses (Dove, 1980). Schooling, therefore, should induce into the youth the knowledge, skills and attitudes appropriate to their contributions in society. There should be relevance between the schools' curricula and the changing economic and social contexts of the community. What learners are taught in schools should endeavour to change in accordance to the emerging issues in order to serve the contemporary society (United Nations Education Science and Cultural Organization (UNESCO), 1998). The influence of schooling is greatest when it is promoting knowledge, skills and attitudes which the community actively accepts and internalises. In rural areas, schools create aspirations in people for a better standard of living and better quality of life. There is value addition when learners participate in the economic activities of their communities after schooling. This reinforces and exemplifies the skills learned at school. Positive community-school linkage provides an opportunity for skill transfer towards community development (Murillo, 2004).

Community-school linkage becomes part of an outreach program for schools where they contribute actively to the efforts of those in community and provide basic skills. The school farm is the agriculture laboratory for the neighbouring communities (Hespe, 2002). Schools-community linkage can also be an in-reach program whereby schools open their doors and allow communities to come and learn certain skills (Murillo, 2004). Schools have been efficient at imparting literacy, innumeracy and basic pre-vocational orientation. Communities have a high desire for these skills when they are relevant to their socio-economic context (Dove, 1980). One of the global aims of education is solving continuing problems that plague humanity such as unemployment and huger. Schools are meant to prepare its graduates for productive work in the community. If youth are oriented positively to life in community, rural life will be enhanced (UNESCO, 1998). According to Dove (1980), the concept of community school should serve the whole community, which is its physical part and encourage the community in efforts which are beneficial to the wider social and economic needs of the society. Schools seem to be most effective as agents in socio-economic development when the social and economic change from back-drop and support community development processes, educational success and best practices including programs that have demand-driven designs (Murillo, 2004).

In the developing countries, governments have made efforts to adopt the schools to the local needs. Schools have been named community schools with an aim of preparing the learners for more productive or effective life in the local community. Currently, the school is perceived as directly functional to personal needs, therefore virtually all communities have become clients of schools. The communities have ambitions for their children to reap the occupational and material benefits of learning (Dove, 1980). Throughout the 19th and 20th centuries, schools have been efficient at producing wage-earners and socializing children into habits appropriate to work in the modern industry. However, there is need for schools to develop the capacity to address emerging community needs and problems (Murillo, 2004).

Education in any society strives to achieve targetable goals. According to the Ministry of Education, science and Technology (MOEST) and the UNESCO, the goals of education in Kenya are:

- $\quad$ To serve the needs of national development;

- $\quad$ To foster and promote national unity;

- $\quad$ To prepare and equip the youth to play a leading role in the life of a nation;

- To assist in promotion of social equality, train in social obligation and responsibility;

- To foster and develop our rich and varied cultures; and

- To foster and promote international consciousness and unity.

\subsection{Genesis and Growth of Agriculture Education in Kenyan Schools}

The agricultural sector is projected to grow at about 4-6 percent per annum if it has to contribute to national growth, and increase rural wealth (International Monetary Fund (IMF), 2000). With 80 percent of the population and the majority of the poor found in the rural areas, and relying upon small-holder farming at subsistence levels. It is evident that poverty 
reduction calls for higher agricultural growth rates. Agricultural growth can catalyse growth in other sectors, with an estimated growth multiplier of 1.64, compared to 1.23 in non-agricultural commodities (IMF, 2003).

To achieve the projected growth rate in agriculture sector, however, the most precious resource would be the people regardless of their gender, age, and geographic location, and secondly their potential to work for the collective betterment of Kenya (IMF, 2000). Human resource development through education translates to creation of labour and employment. This in turn trigger the improvement in provision of knowledge, skills and attitudes for the work-force, stimulation of economic growth, maximization in utilization of labour, and human resources in income generating opportunities. This underlies the reason why agricultural education is given prominence in this survey for its role in creation of human resource.

Agricultural education in Kenyan Secondary Schools bears its origin from Chavakali secondary school in western Kenya, where it was initiated by Robert Maxwell in 1960. The programme had three basic objectives:

- Making rural secondary education more practical and more responsive to developmental needs of Kenya; Developing the school as a demonstration area, and generate enthusiasm and willingness to work among the students; and

- Relating agricultural subject to: the entire school programme, development of the region and country and life and future of the students (Maxwell, 1960).

These objectives were consistent with the name of the subject at that time that is vocational agriculture. It was seen as a subject that would result in a reasonable amount of technical training among students. The subject aimed at making a student fit for effective employment in agriculture (Maxwell, 1960). At the early stages, the pilot project met with apathy because members of the community viewed agriculture as an occupation for those who lacked school education (Kathuri, 1990). This view was also directed towards those who were unable to make it through education system or other basic science subjects and hence agriculture was seen as a dirty job (Stabler, 1969).

Agriculture subject became officially established in the school curriculum at several phases in the slow development of colonial education (Sheffield, Morris \& Hermans, 1976). The Ominde Commission of 1964 observed that, very little had been done towards training students in practical skills. The Commission emphasized the need to prepare secondary school students to take an active role in farming processes, besides preparing them for further studies in agriculture. A number of national development plans prepared after 1964 (GOK, 1966; 1970; 1974; 1979) took the Commission's observations seriously and made provisions for expansion of agricultural education to have more secondary schools teaching agriculture. Subsequent reports (Weir, 1967; Bessey, 1972; GOK, 1976) and studies (Maxwell, 1970; Sheffield, 1976; Onyango, 1975; Sheffied et al,. 1976 \& Kathuri, 1981, 1986, \& 1990) have consistently shown that there is a lot of potential for making the subject more pragmatic and useful to national development.

Mosher (1971) described various ways in which farming activities in rural areas can be purposely accelerated to enhance economic development. One of the ways was provision of agricultural education and training through schools, colleges, and extension education, including youth clubs. According to World Bank (1988), "without education, development will not occur. Only an educated person can command the skills necessary for sustainable economic growth."

\subsection{Practical Agriculture and Self- Reliance in Farming}

Bessey (1972) advised the Government of Kenya that, the methods suited to the needs of the rural small-scale farmers be incorporated in to agricultural education programme to enhance self-reliance skills to would-be SSAGs. He further suggested that, the school teaching facilities should include small crops, and livestock enterprises to assist the learners gain the practical skills, geared towards self-employment and sustainability. Later on, GOK (1976) also suggested that, the curriculum for both primary and secondary schools should endeavour to prepare students for agriculture budgeting, the family welfare, and community development. It, in addition, suggested that, the teaching of agricultural science, including the economics of production be incorporated in the syllabus. The same report recommended that secondary education be geared towards the rural and informal sector by diversifying the curriculum and giving priority to teaching agricultural science (GOK, 1976). There was further emphasis on practical agriculture for self-reliance and sustainability in farming. It is from the above reports that the general objectives of teaching agriculture were developed. Although agriculture was taught before 1976, it was more elaborate than it is currently.

The teaching of skills necessary for self-employment and self-reliance is only possible where there are adequate and proper materials and human resources (KIE, 1992). The resources include school farms and competent and trained agriculture teachers. The teaching of agriculture has improved over the years to reflect the practical orientated approach. Among the steps undertaken by the Kenya Government (KIE, 1992) through Ministry of Education (MOE) include, ensuring that every school offering agriculture as an elective subject either owns or hires a farm for practical purposes. And should include the project work (Agriculture Practical Paper 3) as stipulated in the Kenya National Examination Council (KNEC) in 1985. Where students should fully participate in developing their psychomotor skills, hence become self-reliant and better farmers after completing their formal education (KIE, 1992).

The Kenyan secondary schools agriculture syllabus was developed with a view to accomplish two fundamental objectives, the development of the basic principles of agriculture production relevant to Kenya in general and specifically to learner's environment. The second major objective is involvement of the learners in practical's aimed at making them to acquire the necessary skills useful in agricultural practices in all types of environments. The syllabus recommends that the 
teacher and the learners should select study crops and livestock that are most suited to the student's geographical areas for study (GOK, 2004).

Other objectives are:

- Reinforcement of interest and awareness of opportunities existing in agriculture;

- demonstration that farming is a dignified and profitable occupation;

- expansion of knowledge of basic principles and practices of agriculture;

- development of an understanding of the value of agriculture to the family;

- $\quad$ provide a background for further studies in agriculture;

- $\quad$ develop self-reliance, resourcefulness, problem-solving abilities and occupation outlook among learners; and

- Ensure that learners take an active part in rural development by integrating agriculture activities in the curriculum (GOK, 2004).

\subsection{Theoretical Framework of the Study}

The survey was guided by Carney's (1999) theory, on "Sustainable livelihoods". This theory describes the sustainable livelihoods framework as a tool that can define the scope and provide the analytical basis for livelihoods analysis, by identifying the main factors affecting livelihoods and the relationships between them. Carney outlines a factor like, human/ social resource and the livelihood opportunities, and the way they interact at micro, intermediate, and macro levels, gradually shifting to livelihoods (Carney, 1999). A key feature of sustainable livelihoods framework is its recognition of people as the actors, with knowledge and skills as assets that are capable of rational action in pursuit of their own livelihood goals. The framework also recommends for the initial emphasis on resource management to shift gradually to livelihoods after knowledge and skills (assets) acquired at school are fully utilized (Tyler, 2006). In this study, livelihoods related to performance in farming, whereas Carney's factor (human/ social resource) related to the grade achieved in agriculture at school investigated in the study.

\subsection{Conceptual Framework of the Study}

In this study, therefore, performance in farming has been related to Carney's livelihood factor, as grade achieved in agriculture at KCSE examinations and its influence on performance in farming.

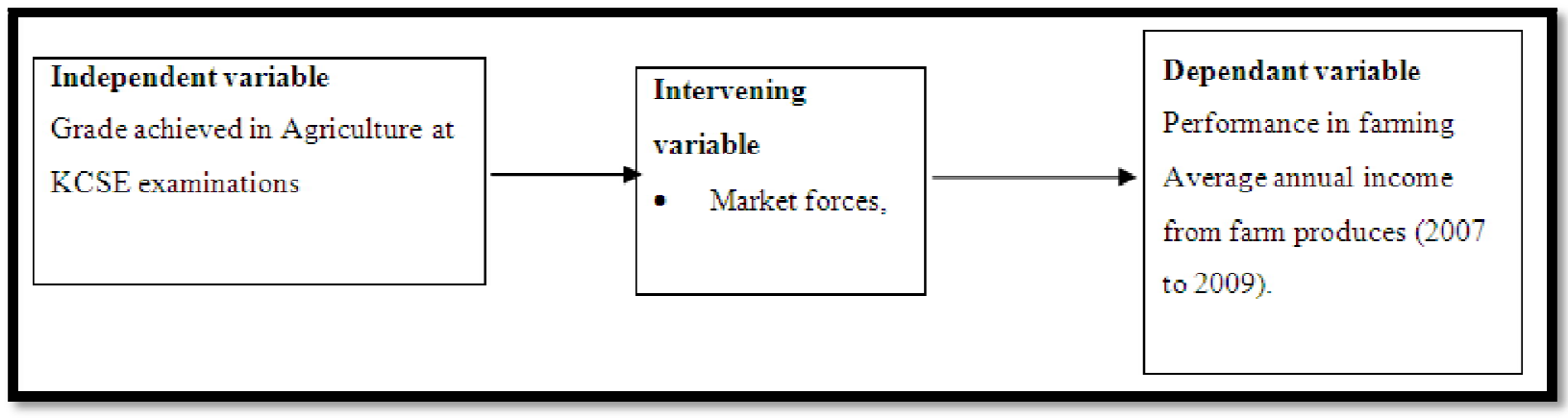

Figure 1: Conceptual Framework of the Relationship between Independent, Intervening and Dependent Variables

The study entailed the use of a conceptual framework which related independent variable (grade achieved at KCSE) and the dependent variable (performance in farming), and the intervening variable (market force, (Figure 1).

The independent variable in (Figure 1), with respect to independent and intervening variable(s) were measured as follows: on the influence of agriculture performance in KCSE examinations on performance in farming, respondents were required to supply information on the grade scored by ticking against a grading scale of A, B, C, D and below D. Where D and below = below average; $\mathrm{C}=$ average and $\mathrm{B}$ and above $=$ above average.

The dependent variable on performance in farming was determined by subjecting the respondent to supply information on categorized ranges of annual income from the agricultural enterprises for the last three years (2007-2009) so as to get estimates of total and average revenues obtained from the farm per annum. Lastly to minimise the effects of the intervening variable (market forces,) statistical testes (categorical regression and Chi-square) with an error allowance of 0.05 alpha level were used. 


\section{Research Methodology}

\subsection{Research Design}

The research design chosen for the study was ex-post facto research design. In ex-post facto design, changes in independent variables have already taken place, and are studied in retrospect for their possible effects on an observed dependent variable (Ary, et al, 1979). The major weakness of the design is control, since randomization and manipulation of the independent variables are impossible. The research design chosen allowed the researcher to apply aspects of survey research to track the specified target population.

\subsection{Location of the Study}

The study was undertaken across the six agro-ecological zones in Kenya. The main agricultural enterprises carried out in across the zones include coffee, maize, beans, pigeon peas, vegetables, fruits crops, root crops, dairy cattle, beef cattle, sheep, goats, poultry, and bees. Due to this wide diversity in terms of crops and livestock enterprises, this study regrouped the enterprises into the following categories for ease of the study; coffee, cereals (maize/ beans/ pigeon peas), horticultural (vegetables/ root/ fruit) crops, dairy cattle, beef cattle/ sheep/ goats, and lastly, poultry production.

\subsection{Target Population}

The target population considered were secondary school agriculture graduates who studied agriculture as an examinable subject and sat for KCSE examinations between 1989 \& 2004. The SSAGs were in addition small-scale farmers residing within their farms in Kenya and practising farming for their livelihoods. A snow ball sampling method of selection was used to draw a sample of 100 respondents as per the recommendations of Kathuri and Pals, (1993); \& Borg, (1987) on the range of subjects befitting representation for various categories of target populations.

\subsection{Sampling Procedure and Sample Size}

The targeted population was scattered over vast areas of the country. Therefore, to access them, the researcher used a snow ball sampling technique (Mugenda \& Mugenda, 2003). A snow ball sampling technique recommends 100 respondents as the minimum number for ex-post facto and survey studies. This sample size was large enough to allow a reasonably accurate interpretation of the results.

\subsection{Instrumentation}

Data was collected using a questionnaire developed by the researcher. A questionnaire in this study was used for its efficiency, economical in utility and practicality besides allowing for the use of a larger sample (Frankell \&Wallen, 2000). Standard instructions were given to all the respondents; in addition, the researcher explained the questionnaire items that were not clear to the respondents as recommended by Ary, et al, (1979). The instrument was designed to capture data from farmers in all aspects mentioned and therefore, meet research objectives. To control the effects of history and maturation, the data were collected at one point in time. To moderate the effects of education, the study only used respondents who had attained secondary school agriculture education. Finally confidentiality was ensured between the researcher and the respondents.

\subsubsection{Validity}

Validity refers to degree to which results obtained from analysis of data actually represent the phenomena under study (Mugenda \& Mugenda, 2003). The instrument used in this study was validated by peers and experts in research field who determine its content and face validity.

\subsubsection{Reliability}

Reliability refers to the internal consistency of the instrument. To ensure the items asked in the questionnaire were reliable, the instrument was pre-tested using a group of 30 SSAGs. This number of respondents was used as per recommendations by Ary, et al, (1979), that, at least 30 respondents is ideal for piloting purposes. The 30 SSAGs used for piloting had closely related characteristics namely: agro-ecological climatic conditions, farm sizes and farming activities to those of the sample population under investigation. Reliability of the instrument was calculated using Cronbach's Coefficient alpha which is a general form of Kuder-Richardson (K-R) 20 formula (Fraenkel \& Wallen, 2000). A reliability coefficient alpha of 0.72 was obtained which was above the recommended minimum coefficient alpha of 0.70 . The questionnaire items which were found to be ambiguous during piloting were re-examined and modified accordingly.

\subsection{Data Analysis}

Once the data collection exercise was completed and raw data were obtained. The researcher organised the data by first coding it before finally key punching it into the computer for analysis. A Statistical Package for Social Sciences (SPSS) software was used for the analysis. Descriptive statistics namely: means/ averages, standard deviations and percentages, were used to analyse the objective. The hypothesis was analysed using a regression analysis test of 0.05 alpha level. The regression used 
was categorical, which is a modification of the simple linear regression, where the variables used are in categorical form. The model adopted was: $\mathrm{y}=\mathrm{a}+\mathrm{bx}$,

Where: $\mathrm{y}=$ independent variable (performance in farming),

$\mathrm{a}=$ constant,

$\mathrm{b}=$ regression coefficient and,

$\mathrm{x}=$ dependent variable (performance at KCSE, perception to farming and farming experience).

Categorical regression analysis test was preferred on the basis of its suitability in comparing two categories (independent variable and dependent variable) of data to describe their relationship, thereby providing a mechanism for prediction.

\begin{tabular}{|c|c|c|c|}
\hline Hypothysis & $\begin{array}{c}\text { Independent } \\
\text { Variable }\end{array}$ & Dependent Variable & Statistical Test \\
\hline HO $_{1: \text { There is no statistically }}$ & Grades & -Average annual & Categorical \\
significant influence of the grade & achieved in & income from sale \\
achieved at KCSE examinations on & agriculture at & regression \\
performance in farming by SSAGs. & KCSE & analysis. \\
& examinations. & & \\
& & & \\
\hline
\end{tabular}

Table 1: Summary of Data Analysis

\section{Results and Discussions}

\subsection{Influence Grade Achieved in Agriculture at KCSE Examinations on Income from Farming}

The grade obtained in agriculture in Kenya Certificate of Secondary Education (KCSE) examinations were observed in relation to the level of performance in farming from the diverse agricultural activities carried out by secondary school agriculture graduates on their farms. The agriculture grades were grouped as grades $\leq \mathrm{D}=$ below average, $\mathrm{C}=$ Average and $\geq \mathrm{B}$ $=$ above average. The average levels of income against which objectives 2 to 6 , and hypotheses 1 to 5 were examined are: Kshs. $\leq 40,000=$ Below average, between Kshs. 40,000 and 80,000 =Average and Kshs. $\geq 80,000=$ Above average.

- Objective: To examine whether the grade achieved in agriculture at Kenya certificate of secondary education (KCSE) examinations influences performance in farming among SSAGs

This objective determined whether the grade obtained in agriculture in KCSE examination influenced performance in farming with respect to average income obtained from agricultural undertakings carried out per annum. The respondents were required to supply information on the grade scored in agriculture at KCSE examinations by ticking against the grades listed down on a grading scale of A, B, C, D and Below D. The data generated from the objective were analysed using means/ averages and percentages, and ranked on the basis of: below average, average and above average. The results obtained are presented in Tables 9, 10,11,12,13,14, 15 and 16.

\subsubsection{Influence of KCSE Examinations Grade in Agriculture and the Income from Poultry Production}

The findings on influence of KCSE examinations grade in agriculture on income from poultry production are presented in Table 2, followed by discussions.

\begin{tabular}{|c|c|c|c|c|c|}
\hline \multirow{2}{*}{ Enterprise Income } & \multicolumn{2}{|c|}{ Grades in Agriculture at KCSE Examinations } & \multirow{2}{*}{$\mathbf{N}$} & \multirow{2}{*}{} \\
\cline { 2 - 5 } & $\begin{array}{c}\text { Above average } \\
\geq \mathrm{B}\end{array}$ & $\begin{array}{c}\text { Average C } \\
\text { Below average }\end{array}$ & & \\
\hline Below average & 3 & 43 & 39 & 85 & 94.4 \\
\hline Average & 0 & 1 & 0 & 1 & 5.6 \\
\hline
\end{tabular}

Table 2: SSAGs Agriculture Achievement at KCSE Examinations and the

Income from Poultry Production

The findings were that, a total of 86 secondary school agriculture graduates (SSAGs) out of 100 practised poultry production. Income from poultry for most respondents (94.4\%) was ranked "below average", while 5.6\% was ranked "average".

\subsubsection{Influence of KCSE Examinations Grade in Agriculture and Income from Cereals Production}

The crops categorised under cereals were: maize, beans and pigeon peas. Findings on influence of KCSE examinations grade in agriculture on performance in cereal production are presented in Table 3. 


\begin{tabular}{|c|c|c|c|c|c|}
\hline \multirow{2}{*}{ Enterprise Income } & \multicolumn{2}{|c|}{ Grades in Agriculture at KCSE Examinations } & \multirow{2}{*}{$\mathbf{N}$} & \multirow{2}{*}{} \\
\cline { 2 - 6 } & $\begin{array}{c}\text { Above average } \\
\geq \mathrm{B}\end{array}$ & $\begin{array}{c}\text { Average } \\
\text { C }\end{array}$ & $\begin{array}{c}\text { Below average } \\
\leq \mathrm{D}\end{array}$ & & \\
\hline Below average & 4 & 48 & 45 & 97 & 98 \\
\hline Average & 0 & 1 & 1 & 2 & 2 \\
\hline
\end{tabular}

Table 3: SSAGs Agriculture Performance at KCSE Examinations and Income from Cereals

The findings were that, a total of 99 secondary school agriculture graduates (SSAGs) out of 100 engaged in cereal production. The income from cereals for most SSAGs (98\%) was ranked "below average", while (2\%) was ranked average".

\subsubsection{Influence of KCSE Examinations Grade in Agriculture and Income from Horticultural Production}

The crops categorised under horticultural production are: vegetables, fruits and root crops. The findings on influence of KCSE examination grade in agriculture on performance in horticultural production are presented in Table 4.

\begin{tabular}{|c|c|c|c|c|c|}
\hline \multirow{2}{*}{ Enterprise Income } & \multicolumn{2}{|c|}{ Grade in Agriculture at KCSE Examinations } & \multirow{2}{*}{$\mathbf{N}$} & $\%$ \\
\cline { 2 - 6 } & $\begin{array}{c}\text { Above average } \\
\geq \text { B }\end{array}$ & $\begin{array}{c}\text { Average } \\
\text { C }\end{array}$ & $\begin{array}{c}\text { Below average } \\
\text { S D }\end{array}$ & & \\
\hline Below average & 3 & 23 & 20 & $\mathbf{4 6}$ & $\mathbf{9 5 . 8}$ \\
\hline Average & 0 & 1 & 1 & $\mathbf{2}$ & $\mathbf{4 . 2}$ \\
\hline
\end{tabular}

Table 4: SSAGs Agriculture Performance at KCSE Examinations and Income from Horticulture

The findings revealed that, a total of 48 secondary school agriculture graduates (SSAGs) out of 100 practised horticultural production. Income from most respondents from horticulture (95.8\%), was ranked "below average", while (4.2\%) was ranked "average".

\subsubsection{Influence of KCSE Examinations Grade in Agriculture and Income from Coffee Production}

In reference to coffee production, 61 secondary school agriculture graduates practised coffee production. The finding on coffee production is presented in Table 5, followed by discussions.

\begin{tabular}{|c|c|c|c|c|c|}
\hline \multirow{2}{*}{ Enterprise Income } & \multicolumn{2}{|c|}{ Grade in Agriculture at KCSE Examinations } & \multirow{2}{*}{ N } & \multirow{2}{*}{} \\
\cline { 2 - 5 } & $\begin{array}{c}\text { Above average } \\
\geq \mathrm{B}\end{array}$ & $\begin{array}{c}\text { Average } \\
\text { C }\end{array}$ & $\begin{array}{c}\text { Below average } \\
\leq \mathrm{D}\end{array}$ & & \\
\hline Below average & 1 & 24 & 31 & 56 & 91.8 \\
\hline Average & 0 & 2 & 3 & 5 & 8.1 \\
\hline
\end{tabular}

Table 5: SSAGs Agriculture Performance at KCSE Examinations and

Income from Coffee Production

The income for most secondary school agriculture graduates (SSAGs) from coffee production (91.8\%) was ranked "below average", while (8.1\%) was ranked "average".

\subsubsection{Influence of KCSE Examinations Grade in Agriculture and Income from Dairy Cattle Production}

Regarding dairy cattle production, data obtained on this enterprise pointed out that, 23 out of 100 secondary school agriculture graduates practised coffee farming. Table 6 presents the findings.

\begin{tabular}{|c|c|c|c|c|c|}
\hline \multirow{2}{*}{ Enterprise Income } & \multicolumn{2}{|c|}{ Grade in Agriculture at KCSE Examinations } & \multirow{2}{*}{$\%$} & \multirow{2}{*}{} \\
\cline { 2 - 7 } & $\begin{array}{c}\text { Above average } \\
\geq \mathrm{B}\end{array}$ & $\begin{array}{c}\text { Average } \\
\text { C }\end{array}$ & $\begin{array}{c}\text { Below average } \\
\leq \mathrm{D}\end{array}$ & & \\
\hline Below average & 1 & 8 & 9 & 18 & 78.2 \\
\hline Average & 0 & 3 & 2 & 5 & 21.8 \\
\hline
\end{tabular}

Table 6: SSAGs Agriculture Performance at KCSE Examinations and

Income from Dairy Cattle Production

The income for majority of the secondary school agriculture graduates (SSAGs) from dairy cattle production (78.2\%) was ranked "below average", with (21.8\%) ranked "average". 


\subsubsection{Influence of KCSE Examinations Grade from Beef Cattle, Sheep, and Goats Production}

In reference to beef cattle, sheep and goats production, 43 secondary school agriculture graduates out of 100 practised production of beef cattle, sheep and goats in their farms. The findings on beef cattle, sheep and goats are presented in Table 7.

\begin{tabular}{|c|c|c|c|c|c|}
\hline \multirow{2}{*}{ Enterprise Income } & \multicolumn{2}{|c|}{ Grade in Agriculture at KCSE examinations } & \multirow{2}{*}{$\mathbf{N}$} & \multirow{\%}{*}{} \\
\cline { 2 - 6 } & $\begin{array}{c}\text { Above average } \\
\geq \mathrm{B}\end{array}$ & $\begin{array}{c}\text { Average } \\
\mathrm{C}\end{array}$ & $\begin{array}{c}\text { Below average } \\
\leq \mathrm{D}\end{array}$ & & \\
\hline Below Average & 2 & 21 & 19 & 42 & 97.7 \\
\hline Above Average & 0 & 1 & 0 & 1 & 2.3 \\
\hline
\end{tabular}

Table 7: SSAGs Agriculture Performance at KCSE Examinations and Income from Beef Cattle, Sheep and Goats Production

The findings from beef cattle, sheep and goats revealed that, income for most secondary school agriculture graduates (97.7\%) was ranked " below average", with (2.3\%) ranked "above average". In summary, the income for most secondary school graduates from all farming enterprises was ranked "below average". Income from cereals for most SSAGs (98\%) was ranked "below average". Incomes from most respondents from horticulture (95.8\%), coffee (91.8\%), dairy cattle (60\%), beef $(97.7 \%)$ and $(93.4 \%)$ from poultry was ranked "below average". This was irrespective of the KCSE examination grade obtained in agriculture.

- $\mathrm{HO}_{1}$ : There is no statistically significant influence of the grade achieved in agriculture at Kenya Certificate of

Secondary Education (KCSE) examinations on the level of performance in farming by SSAGs

To test this hypothesis, the data were subjected to categorical regression analysis test, which is a modification of the simple linear regression. Results were analysed by comparing various categories of grades obtained at KCSE examinations and the average annual income accruing from all the agricultural activities undertaken to find out whether there is any correlation. The results are presented in Tables 8 and 9.

\begin{tabular}{|c|c|c|}
\hline Multiple R & R Square & Adjusted R Square \\
\hline .158 & .025 & .015 \\
\hline \multicolumn{3}{|c|}{ Table 8: Categorical Regression Findings on } \\
KCSE Examinations Grade in Agriculture
\end{tabular}

\begin{tabular}{|c|c|c|c|c|c|}
\hline & \multicolumn{2}{|c|}{ Standardized Coefficients } & df & F & Sig. \\
\hline & Beta & Std. Error & & & \\
\hline $\begin{array}{c}\text { Agriculture performance at } \\
\text { KCSE }\end{array}$ & -.158 & .100 & 1 & 2.508 & .117 \\
\hline
\end{tabular}

Table 9: Coefficients of KCSE Examinations Grade in Agriculture

The $\mathrm{R}^{2}$ was 0.025 meaning that, the model could only explain $2.5 \%$ of the variability in the dependent variable. The Fstatistic was 2.508 which was not significant $(p=0.117$ at $\alpha=0.05)$. The model cannot be used to explain the variability in the dependent variable. The null hypothesis was accepted. Therefore in this research, performance of agriculture at KCSE examinations could not be used to predict performance in farming.

This finding was unique and disagrees with a common understanding that, persons with good grades at KCSE examinations are expected to perform better in whatever career choice they make than those who obtained poor grades. Studies by Mwangi (1998), and World Bank (1980), elaborate on a positive contributions that education makes to agricultural productivity. In the current study the importance of agriculture in farming was apparent where the aggregate utilisation of secondary education in farming score was very high.

\section{Summary, Conclusions and Recommendations}

\subsection{Summary of the Study}

To achieve the purpose of the study, the specific objective was formulated as: to examine whether the grade achieved in agriculture in Kenya Certificate of Secondary Education (KCSE) examinations influences performance in farming among SSAGs. The hypothesis obtained from the objective was: $\mathrm{HO}_{1}$ : There is no statistically significant influence of the grade achieved in agriculture in KCSE examinations on the level of performance in farming by SSAGs.

The study used an ex-post facto research design. The target population considered for the study included the secondary school agriculture graduates who finished form IV between 1989 and 2004. The preference was those who studied agriculture and sat for its examinations at the final year of secondary school level. A sample size of 100 respondents was obtained through a snowball sampling process who engaged in small scale mixed farming. A well-structured questionnaire was used to obtain the data. The objective of the study was analysed using descriptive statistics including means and percentages. Inferential 
statistics that is categorical regression test was used to analyse the hypothesis at statistical apha level 0.05 . The major findings of the study was that, income for most secondary school agriculture graduates from all farming enterprises was ranked below average irrespective of the grade they obtained in agriculture at Kenya certificate of secondary education examinations.

\subsection{Conclusions}

With regard to objective, hypothesis and the findings of this study, the conclusion drawn from the survey was that, the KCSE examinations grades obtained had positive implications on income from poultry production only.

\subsection{Recommendations}

The findings from this study elicited a number of recommendations that are in line with policy issues revolving around teaching of agriculture subject in secondary schools. The recommendations are:

- This study recommends that agriculture syllabus should focus toward creation of self-employment among secondary school graduates.

- Secondary school agriculture should be backed with post-secondary training on farming to fully orientate secondary school agriculture graduates.

- The agriculture teachers should inculcate positive attitude to learners in order for them to appreciate farming as a business with potential employment opportunities.

- Agriculture teachers should reinforce the agriculture learning through community outreach programmes where learners interact with agriculture researchers and commercial farmers.

\section{References}

i. Borg, W.R. (1987). Applying educational research. A practical guide for teachers (2nd ed). New York: Longman, Inc. White Plains.

ii. Carney, G., Drinkwater, M., Rusinow, T., Neefjes, K., Wanmali, S., \& Sigh, N. (1999). Livelihood approaches compared. London: McGraw Hill Publishing.

iii. Chitere, P.A., \& Van Doorne, J.H. (1985). Extension education and farmers performance in improved crop farming in Kakamega District. Agricultural Administration, 18(2), 8-13.

iv. Dellere, R. (1988). Food and nutritional strategies concepts: Objectives and application. Brussels: Royal Academy.

v. Dove. A. Linda. (1980). Role of schools in communities Development, London: Journal of Comparative Education. 16 (1) 17 $-21$

vi. Fraenkel, J. R., \& Wallen, N. E. (2000). How to design and evaluate research in education. (4th Ed) New York. McGraw Hill Publishing W.

vii. Government of Kenya (GOK). (1964). Kenya education commission report, part 1. Nairobi: Government Printer.

viii. Government of Kenya (GOK). (1966). Development plan (1966 - 1970). Nairobi: Government Printer.

ix. Government of Kenya (GOK). (1970). Development plan (1970 - 1974). Nairobi: Government Printer.

x. Government of Kenya (GOK). (1974). Development plan (1974 - 1978). Nairobi: Government Printer.

xi. Government of Kenya (GOK). (1976). Report of the national committees of education objectives and policies. Nairobi: Government Printer.

xii. Government of Kenya (GOK). (1979). Development plan (1979 - 1983). Nairobi: Government Printer.

xiii. Government of Kenya (GOK). (2006). Strategic development plan (2006-2010). Nairobi: Government Printer.

xiv. Government of Kenya (GOK). (2004). Education sector strategy plan, Ministry of Education, Science \& Technology, Nairobi: Government Printer.

xv. Government of Kenya (GOK). (2009). The 2009 Kenya Population \& Housing Census. Nairobi: Government Printer.

xvi. Hespe, S. (2000). Expert opinion on the future of Agricultural Education, Ilinois, USA: Urban Champaign Press.

xvii. International Monetary Fund (IMF). (2000). Interim poverty reduction strategy papers. Washington, D.C: International Monetary Fund.

xviii. Kathuri, N.J. (1981). The status of agriculture and its relevance to schools, colleges, and universities of Kenya. Proceedings of the third Conference of Kenya Agriculture Teachers Association. Njoro: Egerton University.

xix. Kathuri, N.J. (1986). Prospects and problems in secondary schools agricultural education programme of Kenya. Nairobi: Kenyatta University.

xx. Kathuri, N.J. (1990). A Study of the new agricultural education in the secondary schools of Kenya (Unpublished Ph.D. Dissertation). Urbana Champaign: University of Illinois.

xxi. Kathuri, N.J., \& Pals, A. (1993). Introduction to educational research. Njoro, Kenya: Educational Media Centre, Egerton University.

xxii. Kenya Institute of Education (KIE). (1985). Secondary school agriculture syllabus for Kenya Certificate of Secondary School Education. Nairobi: Kenya Institute of Education.

xxiii. Kenya Institute of Education (KIE). (1992). Secondary school agriculture syllabus for Kenya Certificate of Secondary School Education. Nairobi: Kenya Institute of Education.

xxiv. Kenya Institute of Education (KIE). (2002). Secondary school agriculture syllabus for Kenya Certificate of Secondary School Education. Nairobi: Kenya Institute of Education. 
xxv. Kipkemei, P. (2004). Contribution of secondary school agriculture knowledge to rural productivity among small-scale farmers in Uasin Gishu District (Unpublished M.Sc. Thesis). Njoro, Kenya: Egerton University.

xxvi. Maxwel, R.H. (1960). A Pilot agricultural education programme at Chavakali Secondary School. Western Kenya (Unpublished M.A Thesis). Ithaca, New York: Cornell University.

xxvii. Maxwel, R.H. (1970). The relationship between social differences to academic success in secondary schools and occupational patterns in Kenya. The Chavakali Case (Unpublished Ph.D. Thesis). Ithaca, NewYork: Cornell University.

xxviii. Mugenda, O.M. \& Mugenda, G.D. (2003). Research methods: Quantitative and qualitative approaches. Nairobi: ACTS Press.

xxix. Murillo, G. (2004). Education, Entrepreneurship and Community Development Centre for Science Industry and Natural Resources, New York: Shesta College Redding C.A.

xxx. Mwangi, J.G. (1998). Contributions of education and research to national development with special reference to Kenya. Egerton Journal of Humanities, Social Sciences and Education, 2(1), 7-12.

xxxi. Oluoch, G.P. (1982). Essentials of curriculum development. Nairobi: Elimu Bookshop.

xxxii. Onyango, C.A. (1975). The Establishment of secondary school agriculture and its contribution to rural development in Kenya (Unpublished M. Philosophy Thesis), Reading: University of Reading.

xxxiii. Sheffield, J.R., Morris, J. R. \& Hermans. J. (1976). The Agriculture in African secondary schools; Case studies of Botswana, Kenya and Tanzania. 22-38, New York: The African American Institute.

xxxiv. Stabler, E. (1969). Education since Uhuru, the schools of Kenya. Connecticut: Wesleyan University Press.

xxxv. Tyler, S.R. (2006). Communities livelihoods and natural resources. Warwickshire, U.K: Intermediate Technology Publications.

xxxvi. United Nations Education, Science \& Culture Organization (UNESCO, 1998). World conference on higher education, Higher education in the $21^{\text {st }}$ century, vision and action volume 1-plenary. New York United Nations Children's Fund (UNICEF).

xxxvii. World Bank, (1980). Education sector policy paper. Washington D.C: World Bank.

xxxviii. World Bank, (1988). Education in sub-Saharan Africa: policies for adjustments, revitalisation and expansion. Washington D.C: World Bank. 